\title{
A RETURN TO THE TOHUNGA SUPPRESSION ACT 1907
}

Mämari Stephens*

In this article the author revisits the Tohunga Suppression Act 1907 to provide a fresh analysis of the rationale for its passage and subsequent operation. The author challenges the traditional analysis of the passage of the Act as a catalyst to improve Marori health and as a political weapon against the prophet Rua Kenana. Rather, the author suggests that the primary intent of the Tohunga suppression Act was to assert certainty and political dominance at a time both were seen to be absent. The motives of the Maori members in supporting the passage of the bill are also discussed. The article further analyses the operation of the Act. In particular, the pivotal role of the Måori Councils in giving effect to the Act is highlighted as is the cautious approach of the judiciary. In light of these aspects of the Act's operation, the author questions the effectiveness of the Act in achieving its proponents aims.

(1) This Act may be cited as the Tohunga Suppression Act, 1907.

(2) Every person who gathers Maoris around him by practising on their superstition or credulity, or who misleads or attempts to mislead any Maori by professing or pretending to profess supernatural powers in the treatment of cure of any disease, or in the foretelling of future events, or otherwise, is liable on summary conviction before a Magistrate to a fine not exceeding

* This paper was submitted in fulfilment of the LLB(Hons) requirements at Victoria University in 2000 . 
twenty-five pounds or to imprisonment for a period not exceeding twelve months in the case of a second or any subsequent offence against this Act.

(3) No prosecution for an offence against this Act shall be commenced without the consent of the Native Minister first had and obtained.

\section{INTRODUCTION}

In 1907 the New Zealand legislature passed the Tohunga Suppression Act, the product of an anxious and confusing period in New Zealand history. It was passed, in part, as a palliative device to assuage public fears about disturbing millennarian movements and new and uncertain medical technologies. The Act was also passed to allay Päkehä fears about Mäori attempts to claw back some of the political power and representation that had been lost to them over the previous decades of colonisation.

The Act has usually been seen as an attempt to prompt Mäori health reform and to neutralise powerful Mäori leaders, particularly Rua Kenana. Certainly these aspects provided much of the rhetoric surrounding the passage of the Act, but in fact the Act was never used to fulfil these two aims. The primary intent of the Act was symbolic; to reassert certainty and political dominance at a time where both were seen to be lacking.

Any discussion of the purpose and intent of the Act must also include analysis of how the Act was actually used. The Courts applied the Act cautiously indeed and the judicial approach appears to have undermined what looks at first glance to be a very prescriptive piece of legislation. The Act was also used by certain elements of the Mäori community to achieve political aims not foreseen by the legislature. This judicial restraint coupled with attempts by Mäori to use the Act for partisan aims undermined the overall effectiveness of the Act.

It cannot be argued entirely that the Tohunga Suppression Act was used effectively in the suppression of Mäori spiritual practices. 
Today the Act is often viewed in this light, but the available documentary evidence does not fully support such an interpretation.

This essay has two sections. The first examines the historiographical, historical and legislative contexts of the Act, demonstrating why the Act was passed. The second section investigates the complaints and prosecutions brought under the Act. This section also looks at previous legislation as well as the responses of the Courts and Mäori communities to the legislation. Finally this essay appraises the effectiveness of the Tohunga Suppression Act.

\section{A A Historiography}

According to the interpretations of writers such as Judith Binney, Peter Webster, Rayburn Lange and Malcolm Voyce, the Act was a measure initially prompted by Mäori and Päkehä concerns over the appalling state of Mäori health in turn-of-the-century New Zealand. The Act, according to this view, was designed in part to counteract the consequent rise of tohunga untrained in current Western medical techniques. ${ }^{1}$ The other major catalyst for the Act, according to these commentators, was the perceived danger posed to Europeans by the Tuhoe prophet Rua Kenana. ${ }^{2}$ Some writers acknowledge the passage of the Act as a direct attempt to counteract the growing influence of such charismatic and powerful spiritual leaders who were potentially

1 See $\mathrm{R}$ Lange May the People Live - A History of Mäori Health 1900-1920 (Auckland University Press, Auckland, 1999) 44 onwards; R Maaka"Why the Tohunga Suppression Act 1907?" in A Talu and M Quanchi Messy Entanglements: Papers of the $10^{\text {th }}$ Pacific History Association Conference (Brisbane, 1995) 181; P Webster Rua and the Mäori Millennium (Victoria University Press, Wellington, 1979) 148; J Binney, G Chaplin and C Wallace Mihaia: The Prophet Rua Kenana and his Community at Maungapohatu (Oxford University Press, Wellington, 1979) 25; J Cody Man of Two Worlds: Sir Maui Pomare (AH and AW Reed, Wellington, 1953) 60.

2 See particularly Voyce "Mäori Health in NZ: The Tohunga Suppression Act 1907" (1989) 60 Oceania 2, 109-110. 
subversive: "asserting a power and control inimical to law and order". ${ }^{3}$

These commentators generally recognise the Tohunga Suppression as an inefficient piece of legislation because the practice of tohungaism did not seem to die out at the expected rate. ${ }^{4}$ Furthermore Rua Kenana was never convicted under the Act. Voyce maintains that the Act was a failure because of the clash of cultural imperatives: ${ }^{5}$

Mäori were reluctant to inform on tohunga and invite supernatural

retribution. Likewise this legislation was ineffective in modifying

Maori belief in the supernatural cause of disease.

Undoubtedly traditional aspects of tohungaism did resist legislative intervention. However the reasons for the passage of the Act and its apparent failure are more complex than has been previously recognised and deserve further exploration.

\section{B Tohunga - A Definition}

At its most basic meaning the term tohunga merely refers to an "expert". ${ }^{6}$ Perhaps because of the wide application of such a term the Legislature completely failed to agree on a legal definition of tohunga in 1907. The term was eventually taken out of the original bill although it was retained in the preamble. ${ }^{7}$ The omission was seen to avoid the prosecution of those who were merely harmless herbalists

$3 \mathrm{R}$ Hill the Iron Hand in the Velvet Glove: The Modernisation of Policing in New Zealand 1886-1917 (Government Printer, Wellington, 1995) 137; Lange, above $\mathrm{n} 1,249$.

4 See Lange, above $\mathrm{n} 1,254$ onwards.

5 Voyce, above n 2, 99.

6 H Williams A Dictionary of the Mäori Language (Government Printer, Wellington, 1985) 431. See also TG Hammond "The Tohunga Maori" Journal of the Polynesian Society (1908) 17, 67.

7 (22 August 1907) 139 NZPD 381-383. 
or experts in traditional lore as opposed to the persons targeted by the Act: 8

The term, as used in the legislation, cannot be interpreted by traditional understandings of what tohunga are and were. The word "tohunga" in the Act, and in this paper only refers to a legal label for the people who committed the specific offences created by the Act. ${ }^{9}$

\section{WHY WAS THE ACT PASSED?}

The Tohunga Suppression Act emerged at the intersection of several potent elements in New Zealand history. In addition to the health concerns and the fears about leaders such as Rua Kenana, other factors render the Act an interesting photograph of an anxious time.

\section{A Mäori Health}

While the Mäori population had increased slightly from 1906 to 47,732 there was still a feeling in 1907 that the Mäori race was about to become extinct. ${ }^{10}$ In 1907 many Mäori were still unable to access consumption sanatoriums or hospitals, and the numbers of doctors subsidised to treat Mäori patients in rural areas were pitiful. For example, there was one doctor at opötiki for 3,500 Mäori in the Urewera and the Bay of Plenty. ${ }^{11}$ The national health vote for Mäori

8 For example, Louisson in the Parliamentary debates states: "That, I think shows that the Bill is intended to deal with persons who desire to use unsatisfactory means, and those persons are called merely tohungas. If the good tohunga does exist, he is not interfered with." (22 August 1907) 139 NZPD 384 .

9 The offences created by the Act are discussed in the second section of this paper.

10 Archdeacon Walsh "The Passing of the Mäori" (1907) 40 Transactions of the New Zealand Institute 154.

11 See also A Ward A Show of Justice: Racial "Amalgamation" in Nineteenth Century New Zealand (Auckland University Press, Auckland, 1995) 141-142, 202 onwards for a brief discussion on reasons for the paucity of medical practitioners among Mäori in the $19^{\text {th }}$ century. 
for 1907 was $£ 3,000.00$, the vast bulk of which was paid in medical subsidies to doctors, leaving approximately $£ 800.00$ for the purchase of medicines. As Ngata despaired: "Amongst forty-six thousand people what is $£ 3000 ? " 12$

This lack of facilities necessitated the use of tohunga untrained in Western medicines. ${ }^{13}$ Such tohunga often used methods that were dangerous to their patients, such as placing fever-patients in cold water. While Päkehä commentators have been very critical of such techniques, these were not necessarily novel developments; tohunga ahurewa (ritual experts) had used such methods in the lifting of tapu. As Voyce points out, it was the inappropriate use of traditional methods in new situations that, on many occasions, proved fatal. ${ }^{14}$

In light of these techniques, and after seventeen children died in one pä alone after the ministrations of tohunga, Mäori Health Officer Dr Mäui Pömare pushed, in his 1904 annual report, for legislation against the practices of tohunga. ${ }^{15}$ This report was one of the main drivers for the eventual passage of the legislation. However, while Pömare was passionate in his campaign against tohungaism, other Mäori support for legislation against tohunga, as will be seen below, was more equivocal.

12 Ngata (19 July 1907) 140 NZPD 521. The vote from the Civil List did not increase until 1917 when it was raised to $£ 3,600$ : See Lange, above n 1, 184 .

13 A similar situation to that of London of the $17^{\text {th }}$ century, where the ratio of qualified doctors to the London population "can never been less than five thousand to one and was usually very much greater". K Thomas Religion and the Decline of Magic (Penguin, London, 1971) 12. This was an era when many of the poorest inhabitants turned to unqualified and "untrained" healers such as herbalists, wise-women or other such practitioners, who will have carried out similar functions to tohunga of the late $19^{\text {th }}$ and early $20^{\text {th }}$ centuries in New Zealand.

14 Voyce, above n 2, 101.

15 Minister of Public Health "Public Health Statement" [1904] III AJHR H-31. 


\section{B Fears of New Scientific Discovery and Millennarianism}

The debates surrounding the passage of the Tohunga Suppression Act reveal that the legislators feared uncertainty in medical knowledge and viewed new branches of scientific inquiry, such as meteorology and hypnotism, with caution. They also feared the millennarianism rife among Mäori and Päkehä of the early years of the $20^{\text {th }}$ century.

Members of the House such as Dr Collins and Mr George are quick to cite examples of Päkehä quackery, such as the emergence of hypnotism,
and
propose
that
bill
against 
tohungaism should apply equally to Mäori and Päkehä alike. ${ }^{16}$ George is particularly critical of the recent Government-sponsored rain-making experiments in drought-stricken Oamaru, pointing out that Päkehä needed to look to their own practices before singling out Mäori for legislative attention. ${ }^{17}$

Enhancing this uncertainty was the fear that the country was caught in a series of millennarian "crazes". Rua Kenana emerged as prophet and faith healer of the "Mäori Millennium" from at least May 1906. He was one of several charismatic prophet-figures who emerged near the beginning of the century, and represented to the legislature much of the anxiety felt by many in New Zealand about these turn-of-thecentury movements. It is indeed true that Carroll, in introducing the bill to Parliament does use Rua as the nominal example of the evils of tohungaism. ${ }^{18}$ Rua Kenana would have provided the most obvious and contemporary template of a Mäori tohunga that the legislature wished to suppress. It is therefore probable that the majority of the

16 (22 August 1907) 139 NZPD 380. The anxiety that does emerge from the NZPD about the passage of a law dealing only with Mäori reflects a theme that has been common throughout New Zealand legislative history. For example, Colonel AH Russell, as Native Minister in 1865 argued that "true policy requires that all exceptional law should gradually cease and the Natives be encouraged to conform to that of Europeans." Ward points out that such a concern for a system of "one law for all" often disguised a desire to strip away remaining protections for the alienation of Mäori land: Ward, above $n$ 11, 195, 214, 218 and 327. The Hunn report of 1961 sought to eliminate "legal differentiation" between Mäori and non-Mäori. Accordingly, the Tohunga Suppression Act was eventually repealed by the Mäori Welfare Act 1962 .

17 "They pick out a portion of the district where it was not raining - where the sky was blue above them - to show they really could produce rain. Here they made their attempts to bring down the rain - fireworks and all the rest of it, and men rushing here and there in excitement, and no rain fell...[N] ow if the Government is going in for tohungaism in this way, and is going to teach the people a mystic manner in which to produce rain, the Natives are bound to follow in the same direction." (22 August 1907) 139 NZPD $\quad 380-381$.

18 (22 August 1907) 139 NZPD 510-512. 
legislature did in fact envisage his prosecution under the Act. This makes the fact that Rua was never prosecuted even more puzzling. The reasons for this failure are explored later on in this section of this paper.

Other Mäori leaders like Te Ua Haumene, Te Whiti and Te Kooti also emerge from the Hansard debates as notorious prophet figures. However, there appears to be much more discussion of Päkehä prophets and faith-healers in the debates, belying the unease of the Legislature about this period of the century. ${ }^{19}$

The newspapers of the time were themselves partially responsible for the idea that New Zealand was caught in the grip of a tohunga "craze".20 Clearly any "crazes" existed as much among Päkehä settlements as among Mäori and these phenomena, as well as the fear of experimentation and new scientific developments, are part of the tapestry of the Act.

\section{Fear of Mäori Autonomy}

The passage of the Act also reflects an acute Päkehä fear of Mäori aspirations to greater autonomy. Rua Kenana was an obvious symbol of Mäori intentions that was feared by Päkehä. However there appears to have been a concerted effort to whittle away some of the limited opportunities for increased autonomy that the Legislature itself had granted Mäori in recent years. These opportunities were represented by the Liberal Government's passage of the Mäori Lands Administration

19 "Speaker after speaker has pointed out the practice of tohungaism among the Europeans. We know in our own experience what it is...[W]e know there are people in this very city who sold all they had and went off to a city in America called zion under the aegis of the imposter Dowie. We remember a prophet who came here. He prophesied a flood which would destroy the earth, and he invited the elect to go home to a country, the altitude of which he guaranteed to be above the waters of that flood, and many sold out and went there..." (23 August 1907) 140 NZPD 403.

20 Voyce, above n 2, 101. 
Act 1900 and the Mäori Councils Act 1900.21 Certainly these two pieces of legislation were utilised eagerly by Mäori in the earlier years of their operation, often to the exclusion of other institutions. ${ }^{22}$

The Mäori Lands Administration Act 1900 established land councils with particular powers of self-regulation and as bodies empowered to sell and lease Mäori land. ${ }^{23}$ Within a few years these bodies were seen to be taking too much power for themselves in the regulation of Mäori affairs. The councils and their governing Act were often criticised for their perceived failures to facilitate the sale and settlement of so-called "waste" Mäori lands. ${ }^{24}$ A Mäori Land Settlement Act was passed in October 1905 that curtailed Mäori participation in the control of remaining Mäori lands. Land Boards were established and government nominees replaced the elected Mäori members of the councils; one Mäori, two non-Mäori. These new boards had compulsory power over lands not required for occupation by Mäori to lease them out to settlers for 50 years, after which time it was assumed that Mäori would not have the financial ability to pay off remaining encumbrances and regain the land. ${ }^{25}$ By 1906 the Mäori Land

21 Claudia Orange The Treaty of Waitangi (Bridget Williams Books, Wellington, 1992) 227. She observes that these acts allowed a "small degree of local control" as compared to the wider powers that had been requested and presaged by the Native Land Commission of 1891 that had appeared to promise radical changes to land alienation etc.

22 A Ballara Iwi - The Dynamics of Mäori Tribal Organisation from c.1769 to c.1945 (Victoria University Press, Wellington, 1998) 310. See 230 onwards for an account of the operation of other national political movements which operated via committee such as the Kotahitanga movement of the 1890s. These movements aimed at Mäori self-determination and Mäori enthusiasm for the Mäori Council system must be seen in this context.

23 P Spiller, J Finn and R Boast A New Zealand Legal History (Brookers, Wellington, 1995) 156-158.

24 ADL Fraser (19 August 1904) 129 NZPD 573.

25 Herries (23 October 1905) 135 NZPD 968. 
Settlement Act was amended to include the whole of the North Island. ${ }^{26}$ While the Tuhoe were exempted from this legislative action by the Urewera Native District Reserve Act 1896, nevertheless the Tuhoe became increasingly afraid of legislative confiscation of their "waste lands". Such fear was widespread among Mäori at the time of the emergence of the Tohunga Suppression Act.

Another important piece of legislation was the Mäori Councils Act 1900. This legislation originally granted a limited amount of selfgovernance to the Mäori communities. This Act also provided the councils with the power to regulate tohunga in their specific areas. Apirana Ngata describes this Act as a "dead letter" until the point at which the councils decided to implement a standard licensing system. ${ }^{27}$ This system allowed the Mäori Councils to set up their own codes of practice for tohunga as well as sanctions for fraudulent and harmful actions undertaken by tohunga. This fledgling system eventually proved unpalatable to the Päkehä majority, and it is the conflict between the Mäori Councils and the Päkehä legislative majority that appears to have been a crucial element in the passage and implementation of the Tohunga Suppression Act.

Indeed James Carroll himself had not, in 1904, been in favour of specific legislative suppression of tohunga. ${ }^{28}$ He had supported the system set up by the Mäori Councils as a method of bringing tohunga "within the mesh of the law". It was, he said, an experiment, that had been put in place because all other governmental initiatives had failed. ${ }^{29}$ Carroll, as Native Minister, was therefore subject to

26 Maori Land Settlement Amendment Act 1906. See Webster, above n 1, 136.

27 (19 July 1907) 129 NZPD 521.

28 Lange, above $\mathrm{n} 1,244$.

29 (19 August 1904) 129 NZPD 582. 
accusation from Päkehä MPs such as Herries that he favoured and supported tohungaism: ${ }^{30}$

It was a most improper thing that while the whole country was crying out against these tohungas, who wrought untold mischief among the Maoris, the government should actually be licensing them.

By 1907 questions about the actions and intentions of Mäori leadership within the legislature appear to have provided a sub-theme behind the passage of the bill. While Carroll's loyalties had already been impugned in regard to the Mäori Councils, in the Hansard debates of 1907 East Coast MPs Apirana Ngata and Wi Pere also have to offer apologies or retractions to the House for their own activities. Ngata appears to have been at pains to explain his own earlier actions in 1903 when he issued licences to tohunga as the Organising Inspector of the Mäori Councils: ${ }^{31}$

I was told that by issuing licences I was indirectly supporting tohungaism. But the object of having a regulation empowering licences was this: we practically rendered tohungaism illegal except it was conducted under the control of the council.

Ngata comments twice during the course of this speech on being charged with supporting tohungaism, this emphasis perhaps indicating the importance to him of negating the charge in front of his colleagues.

It must also be noted that wi Pere was a strong supporter of the Mäori Councils and also of particular tohunga such as Wereta who was active on the East Coast between 1902 and 1906 . That this was known to the legislature during the debates during the passage of the Act cannot be doubted. Gilbert Mair described Wereta as Wi Pere's "pet tohunga", and Pere was a major patron of Wereta's claim to be Te

30 (19 August 1904) 129 NZPD 581. Lange also notes that Gilbert Mair, the Superintendent of the Mäori Councils, was also opposed to this regulatory system. Lange, above $\mathrm{n} 1,245$.

31 (19 July 1907) 139 NZPD 521. 
Kooti's successor. ${ }^{32}$ Wi Pere was thus known to support a leader that was of the ilk, if not the name, of Rua Kenana. During the debate around the Bill, Wi Pere therefore is at particular pains to excuse his previous statements and disassociate himself from Rua: ${ }^{33}$

I do not want the honourable members to recollect anything I said in another place, where I made a challenge to let me have four thousand soldiers of my own race and I would fight the white people and send them out of the country. I do not want you to say that I am something like Rua...it was the only way in which I could free myself from the turmoil that was within me.

It appears then that the Tohunga Suppression Act to some extent was something of a litmus test of loyalty for some of the Mäori members of the House.

It cannot be said that Ngata, Carroll and others completely endorsed the actions of tohunga. Rather, they recognised the futility in attempting to control by legislation a phenomenon that was beyond the ken and the influence of the Legislature. Ngata, in what was, after all, his first Parliamentary speech in 1907, also issues a warning: ${ }^{34}$

[L]egislate as you will, you will never suppress tohungaism. You cannot do it. All the laws that could be passed in this House could not do it...You are getting down to bedrock when you get to tohungaism.

In view of this statement and his glowing description of the roles and functions of traditional tohunga, his assertion at the end of his speech that he had "very great pleasure in supporting this Bill" leaves questions unanswered. In reality his speech and support of the bill was probably designed to lobby the House for more Mäori health resources. The same may perhaps be said of Carroll who beseeches the

32 Lange, above $\mathrm{n} 1,248$.

33 (21 August 1907) 140 NZPD 374.

34 (19 July 1907) 139 NZPD 520. 
House at the end of the first reading to increase the funding for Mäori health needs, in complete agreement with the observations of Ngata. He suggests diverting rentals from the West Coast settlement reserves and upping the annual allocation from the Civil List. ${ }^{35}$

Ngata, Carroll and their other Mäori colleagues may well have believed, in view of the experience of the Mäori Councils, that support of the bill was to have little effect anyway: the tohunga was simply beyond the reach of the courts and of the Legislature. Their support of the bill appears to have posed little threat to the operation of the Mäori Councils (as will soon be shown) and provided a platform for protest about Mäori conditions to the House. These factors, as much as any real concern to eliminate the tohungaism targeted by the bill, appear to have been uppermost in the Mäori support of the Tohunga Suppression Act. Rua Kenana's activities and intentions are also important in trying to determine the political agenda of the Mäori MPs's support of the Act.

\section{The Failure to Prosecute Rua}

The failure to prosecute Rua Kenana under the Act apparently tailor-made for him needs to be explained. Voyce suggests that the lack of prosecutions against Rua under the Act was due to a lack of evidence. ${ }^{36}$ Webster hypothesises that the failure to convict Rua was because Rua ceased to disseminate potentially seditious prophecies about the arrival of the new Mäori Millennium. ${ }^{37}$

A lack of evidence for tohungaism or the cessation of prophecy are not in themselves adequate reasons for the failure to prosecute Rua under the Act. The cases brought under the Act, as described in the second section of this essay, were concerned mainly with healing practices and the gathering of Mäori in one locale around the activities of a tohunga. Prophecy does not seem to have actually been

35 (19 July 1907) 139 NZPD 525.

36 Voyce, above $\mathrm{n} 2,111$.

37 Webster, above $\mathrm{n} 1,224$. 
used as a basis for prosecution, although uttering prophecies did create one of the ways in which an offence could be created under the Act. Rua may have ceased to prophesy publicly, but he was certainly a candidate for prosecution under other grounds in the Act.

Neither does a lack of evidence seem a plausible reason for nonprosecution. There was no shortage of opponents to proffer evidence of Rua's activities. His arch-rival Kereru, together with Akuhata and Te Pouwhare, requested prosecution in December 1907 and Kereru's power in the area could surely have seen enough evidence gathered against Rua. ${ }^{38}$

The most important reason that Rua Kenana was not prosecuted under the Act is that the Government needed his cooperation in the sale of Tuhoe land and gold-mining in the Urewera. ${ }^{39}$ On the $23^{\text {rd }}$ March 1908 the Premier Sir Joseph Ward met with Rua Kenana and his followers at a meeting later to be dubbed the "Ceremony of Union." The purpose of this meeting appears to have been to diffuse tensions between Tuhoe factions prior to a later meeting with the Native Minister Carroll to establish a "general committee" of united Tuhoe leadership empowered to arrange leases and sales of Urewera land. ${ }^{40}$ Webster suggests that Rua used his private interview with Ward prior to this later gathering to hint that he would be prepared to sell land to the Government, thereby gaining political advantage from Kereru. By April 1908 Rua had stated in the New Zealand Herald that he: ${ }^{41}$

wished to create a reserve of some 20,000 acres around his settlement, and that he was quite prepared for certain other areas in the Urewera to be sold to the Crown and opened to European settlement.

38 Letters from Kereru, Akuhata and Te Pouwhare to the Native Minister (24 and 28 February 1908) MA 23/9.

39 Webster, above n 1, 224.

40 Binney, Chaplin and Wallace, above $\mathrm{n} 1,38$; Webster, above $\mathrm{n}$ 1, 226-227.

41 Webster, above n 1, 230. 
These hints of Rua's increasing amenability to the sale of Tuhoe land occur mere months after the final passage of the Tohunga Suppression Act in september 1907. It is conceivable therefore that at least some members of the legislature debating the Act in late 1907 were aware of the political factionalism within Tuhoe, and rhetoric aside, knew that to prosecute Rua under the Act would be selfdefeating for the Government. By 1910, notwithstanding his strong words against Rua in the debates on the Act, Ngata had brought Rua on to the General Committee that had been established as a negotiating body for Tuhoe, and Rua sold some 40,000 acres in the Maungapohatu district to finance his New Jerusalem. ${ }^{42}$

It may therefore be possible to argue that Rua, while providing the Legislature with a handy spectre in the passage of the Act, was never really intended by key members of the legislature as the direct recipient of its coercive powers. ${ }^{43}$ If he was intended as the direct recipient of the legislation, that intention had changed by March 1908.44

\section{E Conclusion}

It appears that the Tohunga Suppression Act was a symbolic gesture to reassert certainty and political dominance at a time where both were seen to be lacking. It was passed in response to a number of fears held by the Legislature of the day. Parliamentarians were influenced by anxieties widely held about new scientific discoveries, new technologies and a general uncertainty about medical knowledge and development. In addition to this fear was a desire to neutralise some

42 (19 July 1907) 139 NZPD 519; Binney, Chaplin and Wallace, above n 1, 41. See also RP Boast "Ngati Whare and Te Whaiti" (1999) Unpublished Report for the Waitangi Tribunal 141-142.

43 See, above $\mathrm{n}$ 18, for references to discussion of Rua Kenana in the debates about the Tohunga Suppression Bill.

44 R Boast, above $n$ 42, 147 notes that Rua Kenana's eventual conviction only took place under the Reform government, with Herries as Native Minister in the place of Carroll. 
of the active proponents of millennarianism that added to an environment of fear and uncertainty in Mäori and non-Mäori communities. Rua Kenana was perhaps the most obvious symbolic target for neutralisation particularly because of his association with Mäori attempts to capitalise on opportunities for autonomy. Whereas the government of 1900 had passed legislation to encourage some limited self-government among Mäori, the climate had changed within seven years. Innovations such as the Mäori Councils and Mäori Land Councils now represented a threat and frustration to Päkehä land development. The struggle for power over the operation of tohunga reflected the conflict between Mäori and Päkehä over the limited autonomy that Mäori had developed for themselves. For the Legislature to wrest control of the practices of tohunga away from the control of the Mäori Councils was a clear roll-back of the powers that had previously been allowed to those councils.

This shift of power away from the Mäori Councils also represented a challenge to Mäori MPs who were in a delicate position. Carroll, Ngata and Pere, all of whom had been tarred with the accusation of supporting tohungaism, indicated their support of the Legislature. It seems they did so probably in the knowledge that the Act could have little practical effect. As will be shown in the second section of this essay, despite this kneecapping of the powers of the Mäori Councils, the Act could not often be enforced without Mäori Council support. The Mäori MPs possibly realised this situation and could afford to support the Act without compromising their Mäori communities as much as might at first be suspected. ${ }^{45}$ The debates also offered an opportunity to lobby (albeit unsuccessfully) for more resources to be directed to Mäori health.

Furthermore it is conceivable that the Mäori MPs such as Ngata and Carroll were aware that use of the Tohunga Suppression Act against Rua

45 The fact that prosecution could not be undertaken, according to 2 (2) of the Act, without the consent of the Native minister was perhaps also seen as an extra precaution that Mäori communities would not be exposed to overt persecution under the Act. 
Kenana could simply not take place if the Government was to achieve its aims of opening up Tuhoe lands for mining and other development. If this was the understanding of the Mäori MPs a few months before Rua's meeting with Joseph Ward, then the characterisation of the Tohunga suppression Act as a palliative symbol may be even more likely.

\section{HOW WAS THE ACT USED?}

This section will investigate the legislation itself. After a brief examination of the earlier legislative precedents, this paper will analyse the offences created by the Act and the actual prosecutions and convictions that occurred. This evidence will show something of the approach taken by the courts and the use made by the Mäori Councils and others of the legislation.

\section{A Previous Legislation}

There had been some legislative attempts to deal with the problem of tohunga prior to 1907. Parliament eventually dealt with some of the fraudulent Päkehä practitioners under the Quackery Prevention Act 1908, indicating that the Tohunga Suppression Act was indeed expected to suppress activities specifically among Mäori communities. Voyce points out that these acts were associated with the health measures of the Liberal legislative programme but cautions that, in practical effect, the Tohunga Suppression Act was part of a series of "coercive measures" directed towards "recalcitrant elements of society".46 He notes, for example, the passage of the Habitual Drunkards Act 1906, the Habitual Criminals and Offenders Act 1906 along with other similar intended measures. ${ }^{47}$ He calls into question any humanitarian intentions of these Acts because it is doubtful that any qualitative improvement to public health resulted from these measures. Certainly

46 K Sinclair A History of New Zealand (Penguin, London, 1959) 187 argues that the humanitarian Liberal legislation programme, particularly of the 1890s, made New Zealand "for a time the most radical state in the world". See also Lange, above n 1, 229 onwards.

47 Voyce, above $\mathrm{n} 2,109$. 
into Mäori health due to the Tohunga Suppression Act. ${ }^{48}$ The Mäori Councils who had been charged with improving Mäori health were granted insufficient resources for this task. ${ }^{49}$

Prior to the passage of the Tohunga Suppression Act, there had been legislation under which prosecutions could be brought for fraudulent and harmful healing practices. Section 240 of the Criminal code Act 1893 had provided for the imprisonment for up to one year of anyone who "pretends to exercise or use any kind of witchcraft, sorcery, enchantment, or conjuration", fraudulently claiming any knowledge or skill "in any occult or crafty science."50 Among the prosecutions procured under that section the tohunga Mapu was convicted at Kaikohe in 1900, Poti was convicted at Wairoa in 1901 while two other tohunga in the same year were convicted in Poverty Bay and Hawkes Bay. ${ }^{51}$

48 For example the vote from the Civil List for Mäori Health did not increase until 1917 when it was raised to $£ 3,600$. Lange, above $\mathrm{n} 1,184$.

49 Evidence in the National Archives reveals the following cases; the first successful convictions were brought against Paku Maki and his wife Hera in March 1910 at New Plymouth. They received three and one month imprisonment respectively (MA 1 1909/703). Puna Himene te Rangimarie was successfully prosecuted in September 1910 at the Hawera Magistrate's Court and fined £10 (MA 1 1910/4915.) Epiha (also known as Hururu) was prosecuted in November 1910 and convicted at the Mercer Magistrate's Court. He was sentenced only to appear if called upon, and to pay costs. (P2/1/29, W 2791 1910-61). In 1911 Te Whare Taha (or Te Whare Wehi) was successfully prosecuted in the Wairoa district and fined a total of $£ 33$ including costs (MA 1 1911/541). Lange, above $\mathrm{n}$ 1, 252 describes Te whare Wehi and Te Whare Taha as separate people, but they are recorded as being the same person in the above file at the National Archives. In 1912 Retete Te Poe was convicted at Kaikohe Magistrate's Court and fined $£ 15$, with three months hard labour in default with one month to pay (MA 1 1912/1372). The next successful prosecution was in 1914 for Päkehä nurse Mary Anne Hill of Grey Lynn (P2/1/29, W 2791 1910-61). Two further convictions were entered for Richmond Rangi in November 1918 at the Port Awanui Magistrates' Court and Matoru at Gisborne in February 1919. (Poverty Bay Herald, Gisborne (New Zealand), 12 November 1918,$2 ; 22$ February 1919, 5). See also Lange, above n 1, 226-228.

50 This section was translated unchanged into s 261 of the Crimes Act 1908 although it did not make the crimes Act 1961.

51 Lange, above $\mathrm{n} 1,243-244$. 
Section 49 of the Indictable offences Act 1894 also enabled such offenders to be fined up to $£ 5$ or imprisoned for up to one month.

The government had thus intended in the earlier years of the century to apply pre-existing legislation such the Criminal code Act 1893 and the Indictable Offences Summary Jurisdiction Act 1894 or even applying charges of manslaughter or failing to provide the necessities of life to practitioners of tohungaism. ${ }^{52}$ By 1906 the Legislature had begun to think a separate Act targeted at Mäori was necessary to deal with a community that undergoing very specific pressures.

For example as Rua Kenana began to exert considerable influence over his followers after 1906, setting up his community in Maungapöhatu, concerns were raised by many Päkehä about Mäori leaving their occupations to follow him. ${ }^{53}$ For Mäori to neglect their employment would eventually cause havoc among the nascent industries of New Zealand. The preamble of the Act would reflect this concern:

Whereas designing persons, commonly known as tohungas practise on the superstition and credulity of the Maori people by pretending to posses supernatural powers in the treatment and cure of disease, the foretelling of future events, and otherwise, and thereby induce the Maoris to neglect their proper occupations and gather into meetings where their substance is consumed and their minds are unsettled, to the injury of themselves and to the evil example of the Maori people generally...(emphasis added)

This excerpt shows the guiding concerns of the legislation to neutralise the apparent threat offered to Mäori employment and community by spiritual leaders such as Rua Kenana. ${ }^{54}$ The offences created by the Act itself are consistent with this preamble.

52 Lange, above $\mathrm{n}$ 1, 244-245.

53 MA $108 / 536(70)$.

54 Voyce, above n 2, 109-110 


\section{$B$ Offences Created by the Act}

The Tohunga Suppression Act proscribes three specific types of criminal wrongdoing:

(i) It is an offence for a person to gather Maori around him "by practising on their superstition or credulity"

This initial sentence reflects the concern about the power of tohunga to draw Mäori away from their usual occupations. This Act makes it a crime to solicit followers, although the crime is only committed by practising on the superstition and credulity of those followers. There is no attempt here to define what beliefs amount to genuine religious practice and what beliefs constitute superstition or credulity. This appears to be left to the discretion of the courts. The courts' interpretation of this issue is discussed briefly later in this section.

(2) It is an offence to mislead or attempt to mislead any Maori "by professing, or pretending to profess, supernatural powers in the treatment or cure of any disease."

The key offence in this section is the exercise of deception upon Mäori. This section operates on the assumption that witchcraft or practices similar thereto are by definition false, and therefore the profession of supernatural powers is always a deception upon the intended recipient. 55 The act forbidden by the Tohunga Suppression Act was not, therefore, the intent to deceive or the actual deception of Mäori, but the actual claim to possess supernatural powers in the treatment of disease. ${ }^{56}$ This prohibition is limited to the practices of healing:

55 Voyce points out that this perspective is a legacy of the Witchcraft Act 1735 (which abolished witchcraft as an offence in England). This Act assumed that witchcraft does not exist and that those who claim it must be fraudulent. Voyce, above n 2, 110.

56 This approach is echoed in the 1921 case Copeland $V$ Cummings [1921] NZLR 326 (SC). Adams $\mathrm{J}$ held that the offence of telling fortunes under $\mathrm{s} 261$ of 


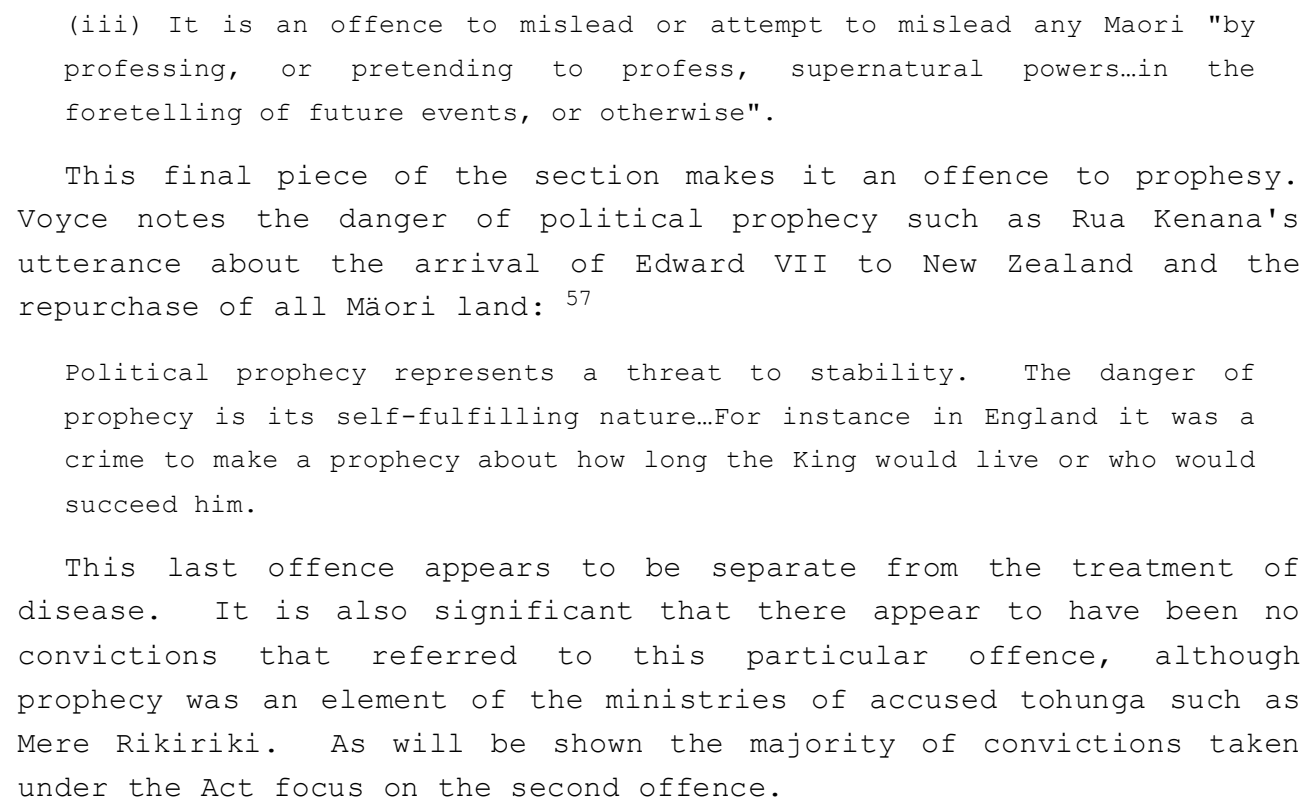

There is evidence available of nine convictions under the Tohunga Suppression Act. These occurred between March 1910 and February 1919.58 It may well be that there were others. Records indicate that other prosecutions were brought, the results of which have not survived, such as the approval given by the Native Minister in August 1914 to prosecute Poi Awarua practising in the Taranaki district. 59

the Crimes Act 1907 remained regardless of the intent to deceive or belief or otherwise of the offender.

57 Voyce, above n 2, 111.

58 See also Lange, above $\mathrm{n} 1,250-253$.

59 MA $114 / 2358$. 
There are also records of several complaints received by the Native Affairs Department that were not acted on due to lack of evidence. ${ }^{60}$

The few convictions that did occur were significant and are worth some analysis, as are the unsuccessful complaints that arrived on the desk of the Native Minister. In short the available material shows that the convictions and the complaints were often motivated by factors other than health concerns. Rather, Mäori political rivalry appears to have been one of the most important factors behind the complaints.

\section{Role of the Mäori Councils in Enforcing the Act}

There are some themes that emerge from the documentary evidence of the cases of tohungaism. Perhaps the clearest theme is conflict between tohunga and their supporters and the local community representatives, including members of local Mäori Councils.

The disgust expressed by the Päkehä members of the Legislature in regard to the Mäori Councils' perceived refusal to cooperate with the sale of "waste-lands" was also expressed about apparent council leniency towards tohunga. After 1903 the Mäori Councils, as has been discussed, took temporary jurisdiction over the tohunga and appeared to utilise a policy of "benign neglect" towards the practitioners. The Tamatea Mäori Council, for example, only considered three major cases of tohungaism, all before 1903, investigating no more before the demise of the Council in 1909.61 Certain Mäori Council members supported noted tohunga such as Hikapuhi, Wereta, Paku Mahi and Hera. Gilbert Mair and Mäui Pomare were among several who doubted the

60 Hikapuhi in the Rongokako District MA 1 08/373; Te Pakeke at Kaupokonui MA 1 08/536; Tangira at Te Kaha MA 1 09/312; Meremere Rikiriki at Parawanui near Bulls MA 1 10/5072; Whaiwaia and Reupena Toromata at Wairoa MA 1 1912/3309; Herewini Huka at Waitotara; Hingaawaka Tupara at Wairoa MA 1 17/55; Rua Kenana MA 23/9.

61 Maaka, above $\mathrm{n}$ 1, 184. 

Councils' overall ability and intent to suppress tohunga activity. ${ }^{2}$
Maori Council chairman and Native Sanitary Inspector Raureti
Mokonuiarangi expressed frustration over the perceived dual loyalties
of the Councils: 63

There are many Councils in this Island, but not all have by-laws to prevent these evil practices. This is partly due to the fact that many of the members of these councils are themselves believers in tohungas.

Some Mäori Councils were certainly active proponents of the Tohunga Suppression Act, and certain council members attempted to use the Act for their own political means. In several cases the local Mäori Council generated the complaints about the activity of tohunga, often sending petitions to the Native Minister. In June 1906 Taiawhio Te Hau, chairman of the Rongokako Mäori Council submitted a petition regarding the female tohunga Hikapuhi. His concern about her activities appeared primarily to relate to the precariousness of his own position on the Council: ${ }^{64}$

Ki te kore e oti he tikanga mo tenei wahine kia kaua e puta mai ki konei

ka puta au ki waho o te kaunihera me te tari whakahaere ora no te mea ki

te hoki mai ko aku hoa mema kai te mahi huna katoa ratou i nga mahi a

Hikapuhi a kai roto hoki etahi o aku mema...kai whea te tuara [o] te

tiamana?

Te Hau was also a leader of the Church of the Seven Rules of Jehovah and was later to follow Ratana. He was the leader of the opposition to Hikapuhi in the Wairarapa. ${ }^{6}$ The conflict between he

62 "Report of the General Conference Held under the Provisions of the Maori Councils Act 1900" [1903] II AJHR G-1, 1.

63 Public Health Department "Annual Report" [1907] AJHR H-31, 55.

64 Letter and petition to the Native Minister (20 August 1906) MA 1 08/373. "If no resolution is found regarding this woman coming here I will resign from the Council and from the Health Department, because my fellow council members are of Hikapuhi, and some of them are in [her party]...where, then, is the backbone of the Chairman?"

65 Lange, above $\mathrm{n} 1,248$. 
and Hikapuhi may be emblematic of the deep political and religious divisions within the Wairarapa area at the time. Raeburn Lange notes that the Church of the Seven Rules of Jehovah had been associated by Päkehä commentators with tohungaism. This association was mainly due to the faith healing and religious leadership of the founder of the church Haimona Patete of Ruapaka, in Marlborough during the $1890 \mathrm{~s}$. Patete himself was to become a founding member of the Arapaoa Mäori Council. 66

In January 1910 Carroll approved the first prosecution under the Act of Paku Maki and his wife Hera. The pair was charged after the death of a young women at Castlecliff. The woman's treatment was paid for by Pokiha her brother-in-law who was the secretary of the Wanganui Mäori Council, later to become its chairman. Pokiha appears to have called in the local Native Sanitary Inspectors, and there appears then to have been a "strong Mäori movement" to get rid of the couple. ${ }^{67}$

A similar situation arose when the chairman of the Kurahaupo Mäori council, Taraua Marumaru laid a complaint against Mere Rikiriki in 1911, making reference to Mere's "party support".68 In that case the police reported that they were "given to understand that most members of the [Kurahaupo] Council believe in this woman."69 This situation indicates that Marumaru may well have been isolated in his position on the Council, and sought support from the Government by means of the prosecution of tohunga.

It appears then, that internecine conflict between Mäori Council members and rival political units was a vital ingredient in many of the complaints laid with the Native Minister for prosecution of tohunga.

66 Lange, above $\mathrm{n} 1,212-13$.

67 Lange, above $\mathrm{n} 1,251$.

68 Marumaru letter to Native Minister (7 November 1911) MA 1 10/5072.

69 Letter from Detective Siddels to the Native Minister (25 October 1911) MA 1 $10 / 5072$. 
The remaining evidence also suggests that the cooperation of the Mäori Councils was often essential to the success of any prosecution. Mackworth, superintendent of the Mäori Councils in 1908 notes his frustration at his reliance on the councils to obtain information about an alleged tohunga at Kaupokonui: ${ }^{70}$

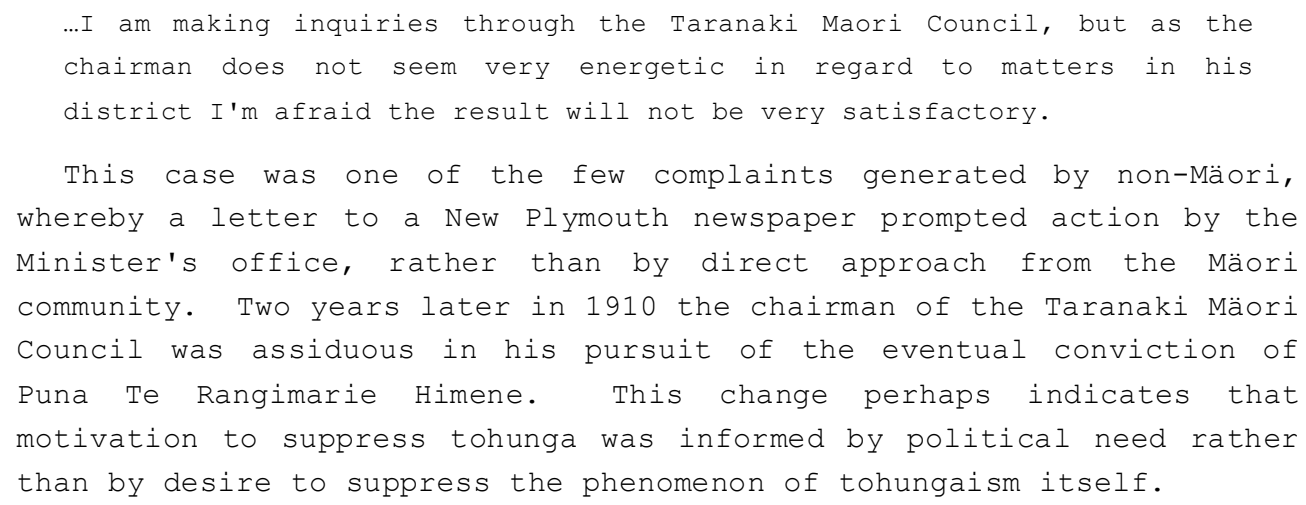

[A] man named Hikiera Poua had a dispute with Reupena some time ago over a plot of land and from that time forward there was a decided coolness between them...[I] have had interviews with numbers of the Mäori who are agitating for the removal of Reupena including Kerei Te Ota, one of the main chiefs of the district, and they one and all admit that he never treats the Maoris in any way for their ailments and has never been known to go near any sick person.

70 MA $108 / 536$.

71 Report of the District Constable (6 October 1912) MA 1 1912/3309. 
Accusations of tohungaism by Mäori against other Mäori were not restricted to matters of land control or political factionalism. In 1921 the Anglican Reweti Kohare accused TW Ratana of tohungaism just as Ratana's own ministry began to be recognised as something quite separate from, and threatening to the mainstream Christian churches of the time. ${ }^{72}$ Ratana himself was careful to disassociate himself from "tohungaism" and no prosecution was forthcoming. This episode shows that the Act may well have been effective in pressuring some Mäori who practised types of healing that could have been covered by the Act to keep their activities away from public view. Similarly this case illustrates that Mäori who practised religious rituals that were not Christian based, or could be questioned as such may well have had their practises curtailed by the presence of the Tohunga Suppression Act.

As surviving records show that Mäori made the majority of the accusations of tohungaism, any retreat "underground" by practitioners will have had to have been from potential Mäori accusers more than from potential Päkehä accusers.

In short, the surviving records of complaints and attempted and successful prosecutions show that complaints were often laid by people with a vested social, political or economic interest in the downfall of the accused. Protestations of tohungaism appear to have been levelled on some occasions against practitioners of orthodox religious beliefs, such as Kaupake Douglas. ${ }^{73}$ It appears there are relatively few requests for prosecutions surviving in government archives that indicate a non-partisan concern to stamp out the practice of

72 A Davidson Christianity in Aotearoa - a History of Church and Society in New Zealand (NZ Education for Ministry Board, Wellington, 1991) 129.

73 Clipping from the New Zealand Herald (8 November 1955) P2/1/29, W 2791 1910-61. 
tohungaism itself, although anti-tohunga rhetoric appears to be utilised in order to provoke ministerial action. ${ }^{74}$

It cannot be stated that all complaints and all prosecutions were politically based. Certainly there was a genuine concern to stamp out harmful healing practices among Mäori communities. The newspaper reports of the convictions of Matoru and Richmond Rangi in 1918 show perhaps that prosecution was motivated by a particular concern for Mäori health, as these tohunga operated during the influenza epidemic. What the documentary evidence shows, however, is that other motives must also be considered when analysing the impact and effectiveness of the Tohunga Suppression Act.

\section{E Attitudes of the Courts}

The penalties given by the courts under the legislation were far milder than those given out under section 240 of the Criminal code Act 1894. The harshest punishment received by tohunga convicted under the Tohunga Suppression Act was the six month sentence of imprisonment given to the "White Tohunga" Nurse Mary-Ann Hill in $1914 .{ }^{75}$ Paku Maki in the "test case" of 1910 received a three-month sentence while his wife Hera received a one month sentence. All other convictions were dealt with by way of fine and allocation of Court costs. This level of punishment is in stark contrast to some of the earlier sentences given out under section 240 of the Criminal Code Act 1894 at the turn of the century. Under that Act the tohunga Poti at Wairoa received six months imprisonment in Napier in 1901 while two other tohunga received

74 The number of requests directed to the Minister appears to prompt the under-secretary Fischer on the 6 February 1914 to remind the department of the "usual practice" for the informant to supply particulars to the police who would then ascertain if the matter should be brought to the attention of the minister under s 2 (2) of the Act (MA 1 14/330).

75 It must be noted that in the in the police file Nurse Hill is reported to have received a sentence of one month imprisonment while in the [1915] AJHR H-31, 26 she is reported to have received 6 months imprisonment. 
12 months imprisonment each in Poverty Bay and the Hawkes Bay also in 1901.76

Given the pressure placed on the Government by 1907 to legislate against the actions of tohunga, the difference between some of the sentences imposed under the Criminal Code Act and the Tohunga Suppression Act is puzzling. There does not even appear to have been a noticeable difference in the severity of offences committed under the Tohunga Suppression Act and earlier measures. ${ }^{77}$ While the Tohunga Suppression Act 1907 has been billed as an "unprecedentedly stringent suppression measure" the Courts never applied its full power. ${ }^{78}$

So we have an Act that was aimed at the prosecution of Rua Kenana and was never used as such. We also have an Act that was a stringent suppression measure that was also never really applied as such by the courts. It has been argued that the problems of gathering evidence precluded the Act being used to its full capacity. ${ }^{79}$ Certainly the police needed the cooperation of the Mäori communities to push successful prosecutions, and often the police were denied that cooperation. However evidential difficulties do not explain the apparent unwillingness of the courts to impose harsher sentences. Judges' notes from Court records are not available for the majority of the convictions and it is not possible to reconstruct judicial attitudes towards the Tohunga suppression Act. It does appear, however, that attitudes towards tohunga had altered between 1900 and

76 Lange, above $\mathrm{n} 1,243-244$.

77 Lange, above $\mathrm{n}$ 1, 244. The convictions under the criminal code were related to deaths as a result of treatment, as were often the cases brought under the Tohunga Suppression Act 1907. Paku Maki and Hera were thought to be responsible for several deaths before their convictions under the Tohunga Suppression Act, as was Poti leading up to his conviction under $s$ 40 of the Criminal Code Act 1893.

78 Lange, above $\mathrm{n} 1,250$.

79 Voyce, above n 2, 113 . 
1910 when the first convictions under the Tohunga Suppression Act took place.

The remaining scraps of information about judicial attitudes suggest that by 1910 the magistrates took a fairly narrow view of the legislation. Judge Acheson, the magistrate of the Kaikohe Magistrate's Court emphasised to Retete te Poe in May 1912 that his conviction was for pretending to possess supernatural powers in the treatment of disease. This conviction was for the second category of offence created by the Tohunga Suppression Act discussed earlier in this section. No mention was made of the two other types of offences; prophecy and gathering Mäori around him. Judge Acheson also warns Te Poe against reappearing in the Courtroom as he had done some 20 years previous for the same behaviour; lest he feel the "full penalty of the law."80 Clearly $\mathrm{Te}$ Poe is a repeat offender, yet even so the Court is prepared to show leniency.

It also appears that judges were concerned to avoid prosecuting individuals who were making a genuine attempt to improve the health of their communities. The defence argued strongly on the behalf of Puna Himene Te Rangimarie, previously a nurse, that she was acting for the benefit of her people. According to the police report after the trial the matter appeared to hang in the balance until Puna stood in Court and stated "But I do possess the mana to cure sickness, I get it through the spirit of my younger sister and I cannot tell my people lies." According to Siddells "This ended the matter" and the conviction was entered, once again on the narrow basis of claiming supernatural powers as opposed to the other types of offences available under the Act. ${ }^{81}$

Another concern shown by the courts appears to be to avoid convicting individuals who were in fact practicing some form of Christianity. The prosecution of Matoru in 1919 showed that the

80 MA 1 1912/1372

81 Report of Detective Siddells (23 April 1910) MA 1 10/4915. 

than mere sectarian prayer upon which to convict.

The concern to preserve genuine religious practice is echoed many years later in the Douglas prosecution of 1955. By this stage even calling upon spirits was no longer sufficient to procure a conviction if genuine (Christian) religious belief and practice was also in evidence: ${ }^{83}$

The Magistrate said that while the prosecution laid much stress on the invocation of spirits, notably Te Wherowhero, there was overwhelming evidence ...that faith in God was the theme of Mrs Douglas...witness after witness had testified that the name of God had been invoked during this ritual.

Despite the scarcity of evidence it is probable that the Courts took a restrictive view of the legislation, tending only to convict where there was plain evidence of the claim to supernatural powers. The Act allowed for a much wider interpretation but the courts seem not to have followed this lead. When the courts did enter a conviction under the Act punishment was lenient compared to sentences passed down at the turn of the century, and the maximum was never applied or even seriously considered.

\section{F Conclusion}

The effect of the Tohunga Suppression Act 1907 appears to have been limited by judicial restraint as well as by the attempted use of the legislation by Mäori communities for partisan ends.

Mäori Councils' support in prosecutions appears to have been pivotal in determining the effectiveness of the Act. Where the

82 "Tohunga at Te Reinga: 'curing' the Influenza" Poverty Bay Herald, Gisborne, 22 February 1919, 5.

83 New Zealand Herald, 8 November 1955. 
Council had the appropriate support and resources, adequate evidence could be collated and conviction pursued more effectively. If the appropriate Council was split or disinclined to pursue prosecution, there appears to have been little aid for the Police and conviction was then almost impossible. For legislation designed in part to neutralise the powers of the Mäori Councils, it became instead, dependent for its success on the cooperation of those same Councils.

While available material is scant, judges by 1910 appear to have been reluctant to impose the full penalties of the Act, and were perhaps also content with a narrow reading of the legislation. While three offences were created under the Act, only the offence of claiming supernatural powers appears to have been applied by the courts. It also appears that judges were reluctant to interfere with genuine religious practices and surviving evidence suggests that the line between genuine religious belief and the claim to supernatural powers was not always easy for a judge to determine, hence a possibly cautious approach.

\section{SOME FINAL CONCLUSIONS}

The Act was the product of political and psychological tensions that prevailed at a unique period in New Zealand history. There were certain overt aims to the legislation, such as the prosecution of Rua Kenana and the improvement of Mäori health, that were not fulfilled. On careful examination of the debates and related sources it appears that another primary intent of the Act was symbolic. It offered opportunities for the Päkehä dominated legislature to reassert certainty in the face of uncertain medical technologies and millennarianism, and to exert political dominance over growing Mäori autonomy. For example, the Liberal Government intended to roll back some of the autonomy that they had previously granted to Mäori in the formation of the Mäori Councils and Mäori Land Councils in 1900.

The Tohunga Suppression Act failed to effectively wrest control over tohunga from Mäori hands. Its passage did bespeak a decrease in the powers of quasi-autonomous bodies such as the Mäori Councils. By the same token, however, the efficacy of the Act depended on the 
cooperation of those same Councils. The prosecutions under the Act were largely governed by Mäori political dynamics. If Mäori practitioners were pushed "underground", and there is some suggestion that this occurred, the fear of prosecution resulted more from the accusations of Mäori than of Päkehä. In the light also of the apparent judicial reluctance to apply the full extent and sanction of the Act to individual cases, the Act failed to neutralise the power of the Mäori Councils and other similar bodies. Tohungaism continued, as did Rua Kenana, and the Mäori Councils remained a thorn in the Government's side, eventually brought down by a lack of resources and coordination. ${ }^{84}$

The Mäori MPs' support of the Act was perhaps well-judged. Some troublesome individuals were neutralised while the operations of the Councils continued, albeit beset by other more serious concerns. Questions of Mäori loyalty to the House were allayed, and negotiations between Carroll, Ngata and Rua Kenana over Tuhoe mining and land-sales continued unaffected by the legislation that was supposed to stamp out Rua's influence altogether. Mäori attempts to use the legislation to gain more health resources for Mäori failed however, and the Act must be seen as a failure in this light.

84 See Ballara, above $\mathrm{n} 22,310-312$ for an account of the demise of the Mäori Councils as Mäori all but abandoned them by 1916 due to a lack of resources and their perceived failure to improve conditions for Mäori in the 1900s and 1910s. See also G Blake-Palmer "Tohungaism and Makutu: Some Beliefs and Practices of the Present Day Maori" (1954) 63 Journal of the Polynesian Society 153 regarding the ongoing practices and features of tohungaism in the post-war period. 